\title{
Marginality and Social Rejection in Amiri Baraka's Slave Ship
}

\author{
Hamid Hammad Abed \\ College of Education for Women University of Anbar, Iraq \\ E-mail: bkhamid2003@yahoo.com
}

Received: 06-08-2016

Published: 10-12-2016
Accepted: 10-10-2016

doi:10.7575/aiac.ijalel.v.5n.7p.158
Advance Access Published: November 2016

URL: http://dx.doi.org/10.7575/aiac.ijalel.v.5n.7p.158

\begin{abstract}
Marginality and social rejection are the most influential matters exploited by Baraka to intentionally criticize the American society. More often than not, these two matters have become the scenes of major or minor acts of humiliation and dehumanization that threaten to violate the ethical rules of living. This paper aims at investigating the impact of marginality and social rejection on a number of black characters in Baraka's Slave Ship who are brought to America to be sold as commodities. It is divided into two sections and conclusion. Section one deals with Amiri Baraka's dramatic thought and experience of marginality within the American society. The textual analysis of Slave Ship is investigated in section two. The significance of the study lies in its textual exploration of the impact of marginality and social rejection in subverting the American dream of democracy, freedom, and equality in Baraka's Slave Ship.
\end{abstract}

Keywords: marginality, Baraka, rejection, slave ship, black

\section{Amiri Baraka: The Playwright}

Amiri Baraka (1934-2014), is one of the most important and articulate writers of the Black Arts movement. He is the genuine representative figure of Black Arts, and he asserts that "the black artist's role in America is to aid in the destruction of America as he knows it"(Gray 2004: 665). After Malcolm X's death, Baraka became a black nationalist, and in 1968 he became a Muslim, a conversion that resulted in the changing of his name. In fact, Baraka has been influenced by Malcolm X, a fiery young ex-convict who was traveling the country preaching a philosophy of black pride, self-help, self-defense, and separation from white people (Simanga 2015: 9). After the assassination of Malcolm $\mathrm{X}$ in 1965, Baraka's ideas changed intensely. Accordingly, Baraka realizes that racial harmony in America is somehow impossible and he starts to urge the blacks to prove their true existence and belonging. Thus, his works are characterized by an angry voice that frequently calls for violence as a means to achieve liberation for blacks. From this point on, Baraka becomes not only an artist and creative voice but also a political leader since he sets "about organizing what would become a highly effective political organization in Newark and eventually nationally" (Simanga 2015:34). His controversial and radical politics have granted him a significant position in the black community, and he has been effective in developing the relationship between black Americans and black Africans.

For Baraka, art is a vehicle for political change, for the liberation and freedom of blacks in particular. This idea has motivated his thinking as he observes that the black man is deliberately marginalized and dehumanized. William Cosgrove (1973: 120) asserts that "the black man is not an integral part of America, that he has no cultural identity, that he is, in a word, invisible". Black power and black culture are inseparable as Baraka argues. Therefore, the transformation of theatre into a medium that advocates the death of the white authority seems a logical step. In his views, the whites are devils and responsible for the humiliation and marginality endured by all blacks. Consequently, Baraka induces blacks to seize control of their lives by expelling all relics of white society and culture from their countries (Houchin 2003: 184). Moreover, Baraka insists that the blacks should join him in becoming a nation of confident warriors to show their pride in their race and expect the future with more dignity, self-respect, and purpose.

Most of Baraka's plays including Slave Ship, are concerned with the relations between black and white people. They are viewed as revolutionary works that display Baraka's awareness of himself "as a leader of a black arts movement that seeks to use drama as a weapon against American racism"(Gray 2004: 666). The term Racism has a long history in western culture, and sometimes the racial naming looks as a stigma in that culture. This stigma is used to marginalize others via uttering the words 'Negro' and 'Black' which are usually heard in American society. When the individuals are referred to as white or black, the implied meaning signifies that the blacks lack many things the whites may possess. Indeed, the racial route is concerned with specific social context that expresses unequal relationship from the authority viewpoint. However, it causes a sense of inequality that is relied on prejudice, bias, poverty, and marginality (Howarth 2006: 443). 


\section{Marginality and Social Rejection in Slave Ship}

To be celebrated and recognized, the play should have significance to a contemporary viewer and reader; furthermore, the author should be a conspicuous one of his or her time. These two elements are criteria for modern literary works and drama in particular. Through exhibiting his dramas, Baraka proves that he is able to activate his audience toward thinking of themselves as the righteous violator instead of the violated. For him, the theatre has to serve in transforming a society. Most of Baraka's plays represent his revolutionary ideas by calling for the unity to achieve a black liberation. It seems appropriate to state that Baraka's Slave Ship reflects certain history of slavery and "its repercussions, beginning with roundup up men, women, and children in Africa to be brought to America for sale"(Abbotson 2003: 93). The black slaves in this play are viewed as socially rejected individuals. Dehumanizing and marginalizing certain individuals will cause hatred, rejection, and violent acts. The social rejection leads to inability of social positive talents such as; thinking, moral reasoning, and empathic sensitivity within passive people (Twenge et al 2007: 56). Accordingly, a socially rejected individual decreases his contact with a group and simultaneously increases his desire to avoid communication as it is so hard to cope with others. He has the feeling of inadequacy and inferiority which leads to improper interpretations for interpersonal behaviours (Luterck et al 2004: 92).

In Slave Ship, most of the characters are nameless to emphasize that they have been treated as animals. This play presents the exploitation and victimization of blacks in America. Baraka strives to assault the moderate views of most middle-class blacks and advocate violence as a means of solving racial conflict. Baraka's play starts with clear signs of humiliation done by the white American against the African slaves. The blacks are treated as animals though they are named as black gold, "Ok, let's go! A good cargo of black gold. Let's go! We head west! We head west"(133). In fact, the racial stigma contains discrimination, and this can be shown via personal or institutional prejudice. This type of racial stigma results in seeing the stigmatized individuals as strangers in their society. Sometimes the racial stigma is built upon incorrect assumptions, for instance the individual is seen according to the physical appearance, the colour of the skin, colour of eyes and hair. Such characteristics are used to identify specific race (Fernando 2006: 26).

Since the black slaves are humiliated and rejected, they are less satisfied with their social lives. They have no means to defend themselves because they are chained when they have been thrown on the ship; therefore, one of them invokes God "Black God? Help me. I be a strong warrior, and no woman. And I strain against these chains! But you must help me, Orisha. Obstalal"(134). The warrior figure in this episode stands for Baraka's declaration that it is a suitable time for the African Americans to recognize their life force and potential for power to become heroes rather than slaves(Abbotson 2003: 94). In advising his black people to confirm their existence, Baraka anticipates that the slaves' sense of community may last long. The contemporary history has witnessed many violent acts through the culture of hatred, rejection, revenge, and marginality. Concealing hatred and rejection for others is offered in different forms; ethnic, race, religious discrimination, besides genocide. Such a type of hatred cannot be erased since it is the source of the social disturbances and the bloody struggles.

A symbolic slave ship is fashioned in the middle of the large playing area. The hold of the ship, where slave bodies are piled in cramped quarters, is eye level with the audience, magnifying the inhuman conditions on board (Felner\& Orenstein 2006: 30). Being weak to offer their children's needs, the black women deliberately killed themselves and their own children:

MAN 1: God, she's killed herself and the child. Oh, God. Oh, God.

WOMAN 1: She strangled herself with the chain. Choked the child. Oh, Shango! Help us, Lord. Oh, please.

WOMAN 2: Why you leave us, Lord?

MAN 1: Dademi, Dademi ... she dead, she dead...Dademi... Dademi, Dademi! (136).

Slavery is both disturbing and ironic, taking place in a land supposedly built on liberty and freedom. Baraka argues that "the exploitation and betrayals have not ended, largely because whites still refuse to accept culpability for what was done, which is one reason he omits any references to emancipation"(Abbotson 2003: 94). For the black slaves, the threat of destitution, marginality and social eviction is very real and inescapable.

No doubt, the social marginality and rejection create many psychological problems, such as; powerlessness, meaninglessness, normlessness, isolation, and self-estrangement (Coser1965:143). Obviously, when the self-respect or dignity of any human being is threatened, he immediately starts to defend himself. Baraka intends to present the black slaves as revolutionary individuals to assert their existence and identity. The conflict between the white Americans and the African slaves on the ship is turned to achieve self- actualization. One of the unnamed black men confirms that he is able to kill the whites though he is bounded by chains. He says" I kill you, devils, I break these chains. I tear your face off. Crush your throat. Devils. Devils"(137). Baraka shows the latent power that comes with an African American ancestral identity and solidarity, the power to cast aside forever the yoke of slavery (Abbotson 2003: 95). This shows Baraka's message for the slaves that the way of black liberation is through killing the whites. Since he arouses the spirit of revolt, tremendous influence on a generation of young African American writers is prepared by Baraka during this period.

To expose the amount of agony, suffering, and exploitation, Baraka follows different styles. Revolutionary ideas and anger are not approaches adopted by Baraka in Slave Ship only, "even in the more purely nationalist writings of the 1960 s and 1970s. His work is also punctuated by cries for help above all, by respect for the energy of black 
people"(Gray 2004: 668). Theatre for him as for his ancestors is a means to provoke the Americans' false claim of democracy and liberty. Theatre history has always relied upon subjective memory, biography, and reviews. Compared to the mountains theatre archives of whites, early African American records are often scare and sometimes contradictory (Hill\& Hatch 2013: xvi).

Baraka's plays are best known for probing social and psychological concerns, including the various manifestations of evil done by the white Americans. Having a penetrating insight enabled Baraka to create a strong black character who strives to get his rights without marginality and humiliation. For this reason, Baraka stands trial before white jury and is found guilty of revolutionizing the blacks against the whites. Thus, he is sentenced to the New Jersey State prison "to serve a term not less than 2 years and 6 months and ordered to pay $\$ 1000$; however, [Baraka] [appeals] the decision and, in time, the conviction [is] overturned during a retrial"(Hudson 1973: 29-31). In Slave Ship, Baraka succeeds in creating a contrasted image through the ceaseless moaning of the slave women to become the symbolic representation of the life of the black people, whereas the whites are defined by their ugly and sarcastic laughter. Marginality and social rejection paralyze one's self-confidence as a member of interrelated human society and stop one's belonging to his group as a real individual. The agony that the act of marginality engraves in the minds and hearts of those who are marginalized is irrecoverable.

There is of course no need to deny the uniqueness of Baraka's work. He is often described as a self-conscious critic of the American life that appears in his plays. He asserts that there is a sort of confrontation between the whites and blacks as if they desired to exchange their roles in life. Robyn Weigman (1995: 99) argues that the fascination of white men with the bodies of "black men issues not only from a desire to destroy the humanity and masculinity of black men, but from a desire to possess that ultra-masculinity for themselves". The different accusations are recorded in this play:

WHITE VOICE: I kill you, niggahs. You black savages.

BLACK VOICE: White Beasts. Devil from hell (140).

In fact, many individuals who have the social authoritative trends believe that good and desirable things for instance; position, wealth, power, food, and care are specified to them only. Whereas other things such as; dangerous works, spite, prison, and death are allotted to an inactive group. Usually, Baraka's plays are not less delicate in their accusation of Anglo- American patriarchal values, and are highly praised for their honesty, exposing the African American identity as a mask, a performance that covers up hatred and anger. However, these plays are also criticized for accepting violence and for their reductive character portrayals and simplification of complex issues (Saddik 2007: 74).

Slave Ship uses a historical framework to obviously call for and predict the death of white power in America. Not only in this play, most of Baraka's words and cultural politics inspired his own desire to use drama as a means to social ends(Krasner 2005: 320). The difference between his earlier plays and this historical concept, is important as it clarifies a shift from works concerned with the individual to material centered on mass collaboration and unity. Besides, Baraka produces what is perhaps his most innovative and challenging drama, Slave Ship is viewed as a moving example of "environmental or living theatre, during this phase of his development" (Andrews et al 2001: 27).

To demonstrate that the blacks could not be easily separated from their roots, Baraka has presented one of his characters as a conspirator or betrayer who plans to escape the brutality and viciousness of the whites but at the expense of the black slaves. The old Tom slave reflects Baraka's image of black integration as white in black face, who murders black consciousness by affirming white as righteous. Tom or the preacher talks as if he was authorized by the black slaves to make an agreement with the whites to be nonviolent. This figure bows and stoops to mollify the oppressors and endear himself (Abbotson 2003: 94). Accordingly, he says: "please, boss, please...I do anything for you... you know that, boss... please... please... (144). By turning slave against slave, the whites dominate all the more easily by fracturing the slaves' sense of unity. The Reverend Turner tries to lead a revolution, but the whites are given advance warning from the betrayer, Tom, and the Reverend is hanged and the rebellion failed. Baraka's Slave Ship visualizes the African American community as the "protagonist braving the abyss, making the tragic journey, and overcoming not only the external onslaughts but also the betrayal and divisions within the community"(Kumar 2009: 49). Implicitly or explicitly, Baraka is ingenious enough in using drama to bring attention to specific concerns of marginality and social rejection in American culture.

Viewing or tracing Slave Ship creates a sense of curiosity of the whites to recognize if they are able to achieve a homogenous life with the blacks. John H. Houchin (2003:185) asserts that on one occasion, a woman honestly wants to know if there is anything whites could do to help. Baraka answers: "you can help by dying, you are a cancer. You can help the world's people with your death". Occasionally, Baraka searches opportunity to insult the white Americans as he never forgets the whites' humiliation and marginality for the blacks. Once, he states:

I came from working-class black people who migrated from the south to Detroit to find work and to escape the violence and humiliation of southern segregation like hundreds of the thousands of black people (Simanga 2015: 34).

Treating the black men as slaves and as second class citizens after slavery relies upon depriving them of that element of existence they perceived as manhood. In slavery times, the slave master could make it with any black woman he could get to. The black man is powerless and helpless to keep his wife and children with him. R.H. Brown (2005:41) 
emphasizes that the social marginality of the black Americans from African roots is almost widely seen in the United States of America. He realizes that there is a strong positive relation between social marginality and social hostility. This type of marginality obstructs the African American individuals to develop their talents to be positive citizens in their society.

A climate of marginality and social rejection emerges to dominate the entire action of this play from its outset. Indeed, social rejection and marginality are widespread phenomena in many societies that have cultural, racial, and ethnic variances. Baraka repeatedly asserts that the black man is not a vital part of America, and that he has no cultural identity of his own. White America is viewed in Baraka's plays and poetry as a subversive force not only for the blacks but for other ethnics. With this in mind, Baraka deliberately shows the celebrating victory of African American over the white oppressive power, but proposes that "African Americans will continue to be on a slave ship until they break out of this prison of history by revolutionary action"(Kumar 2009: 46). Slave Ship ends with triumph to this tragic voyage as the people sing "Rise, Rise, Rise, Cut these ties, Black man Rise, We gon' be the thing we are..."(143). After killing the white voice and the black traitor, the black slaves engage in a victorious dance to express their delight. More importantly, killing the traitor, Tom, drives the slaves to unity, action, and may be to survival. In doing so, the slaves would symbolically break the chains of bondage, ensuring their freedom.

In essence, Slave Ship is able to unify and induce the black audience to stand firmly as a representation of the possibility for collective black commitment outside the theatre. Enmity and threat among individuals never come as a result of materialistic and conditional circumstances, but competition and enmity among them emerge because of the historical developmental rules towards the individual's position in the social order. However, acceptance of diversity among individuals may erase or at least decrease the threat among them (Surda 2013: 13). This notion cannot be fed through speech only but by an actual living without prejudice among the blacks and whites.

Though Baraka is a leading voice in the ritual theatre movement, he also "explores the ways that religious consciousness and ritual structure could trap the unsuspecting"(Krasner 2005: 272). Like other modern American dramatists, Baraka never gives an adequate solution for the problem he tackles, on the contrary, he stings the audience thinking and attitudes. In a way, Slave Ship is open-ended since its conclusion remains consequent upon audience participation in the sacrificial ritual (Kumar, 2009, 50). Morally more than physically, the slaves have been injured since the first hour of their voyage to America. They have been exposed as deprived human beings to enhance the sense of isolation and marginality. The social marginality can be viewed as the individual's feeling of exclusion from perfection and from other aspects of social life. To display the threat of this phenomenon, S. J. Charlesworth (2000: 60) stresses that the social marginality is a great problem that undermines the humanity spirit. Moreover, the marginalized and rejected individual finds himself inactive to control and run his life properly to the extent that he loses the positive care, his present, and future life. However, the relative deprivation causes hostility and hatred among individuals when they lose the motive of achieving valuable subject they aspire to gain whereas it is effortlessly done by other individuals (Bernstein \&Crosby 1980: 444).

\section{Conclusion}

To conclude, the idea that America is a melted pot and the state of democracy and freedom is not true as it is seen by Baraka. Seemingly, America is the state of nonviolence and all its people regardless their colour are equal, but in fact, the blacks are dehumanized and socially marginalized and rejected. Eventually, Baraka's play is a scream against the capitalist America, and he desires to find an adequate social fairness for the oppressed and troubled black people. According to Baraka's personal vision, the American society is lacking love, friendship, intimacy, and mercy, therefore the antagonism and tension among the blacks and whites would gnaw the society's fabric, and silently overthrow the human relationships. In many ways, Baraka has depicted the realistic description to let the viewers to both feel and see the action with their own eyes. More immediately and more importantly, it means that he has experienced the oppression and marginality, with all the extra suffering that each involved. Creating a genuine climate of justice, nonviolence, equality, and transparency in America may stimulate Baraka to reconsider his views of repulsion and antagonism. The sense of convergence between the blacks and whites will be possible if they essentially go forward to end the inherent racial conflict. However, this conflict results in several acts of marginality and rejection which vary in their magnitude and nature of impact. Undeniably, Baraka has successfully used "drama to bring attention to the specific concerns of racial identity and social reform in American culture" (Saddik 2007: 11). Subsequently, he has not realized how to warn against the occurrence of such nasty acts which abolish the individual's identity and, indirectly, society's unity and existence. Yet, he has inflamed the enthusiasm of the blacks to be proud of their African roots and to fight against the threat of inferiority and marginality. Though violent and problematic in his writings, Baraka has been considered as one of the literary pioneers who presents a bunch of individuals capable of celebrating the ecstasy of freedom and triumph through dancing and singing despite their pain and agony. Baraka ends his play no probability of reconciliation between the blacks and whites because they are not ready to hear one another as equivalent citizens.

\section{References}

Abbotson, S. C. W. (2003). Thematic Guide to Modern Drama. London: Greenwood Press.

Andrews, W.L. \& et al. (2001). The Concise Oxford Companion To African American Literature. Oxford: Oxford University Press. 
Baraka, A. (1978). The Motion of History and Other Plays. New York: William Marrow \&Company. All quotations are from the same edition.

Bernstein, M., and Crosby, F. (1980). An Empirical Examination of Relative Deprivation Theory. Journal of Experimental Social Psychology, 16, 442-456.

Brown, R. H. (2005). Culture, Capitalism, and Democracy in the New America. New York: Yale University Press.

Charlesworth, S. J. (2000). A Phenomenology of Working Class Experience. Cambridge: Cambridge University Press.

Coser, R. (1965). Sociology Theory. New York: Macmillan Co.

Cosgrove, W. (1973). Modern Black Writers: The Divided Self!. Negro American Literature Forum, 7(4).

Felner, M., and Claudia, O. (2006). The World of Theatre Tradition and Innovation. Boston: Allyn \&Bacon.

Fernando, S.(2006). Stigma Racism and Power, Aotearoa Ethnic. Net Work Journal, 1(1).

Gray, R. (2004). A History of American Literature. Oxford: Blackwell Publishing.

Hill, E. G., and James, V. H. (2013). A History of African American Theatre. Cambridge: Cambridge University Press.

Houchin, J. H.(2003). Censorship of the American Theatre in the Twentieth Century. Cambridge: Cambridge University Press.

Howarth, C. (2006). Race as Stigma: Positioning the Stigmatized as Agents, not Objects. Journal of Community and Applied Social Psychology, 6(16).

Hudson, T. R. (1973). From LeRoi Jones to Amiri Baraka: The Literary Works. Durham: Duke University Press.

Krasner, David ed.(2005). A Companion To Twentieth Century American Drama. Oxford: Blackwell Publishing Ltd.

Kumar, Nita N.(January 2009). "Form as a Site of Contest: Yoruba Tragedy Turns Revolutionary in Amiri Baraka's Slave Ship." IRWLE. 5(1), 45-52.

Luterck, Jane \& et al. (2004). Interpersonal Rejection Sensitivity in Childhood Sexual Abuse Survivors. Journal of Interpersonal Violence, 19(1).

Saddik, Annette J. (2007). Contemporary American Drama. Edinburgh: Edinburgh University Press, Ltd.

Simanga, Michael. (2015). Amiri Baraka and the Congress of African People: History and Memory. New York: Palgrave Macmillan.

Surda, L. (2013). Stigma Consciousness in The Case of Romanian Rome Activities. Identity and Migration Studies $7(2)$.

Twenge, J., \& et al. (2007).Social Exclusion Decreases Prosocial Behaviour". Journal of Personality and Social Psychology, 11(9).

Weigman, R. (1995). American Anatomies: Theorizing Race and Gender. Durham: Duke University Press. 